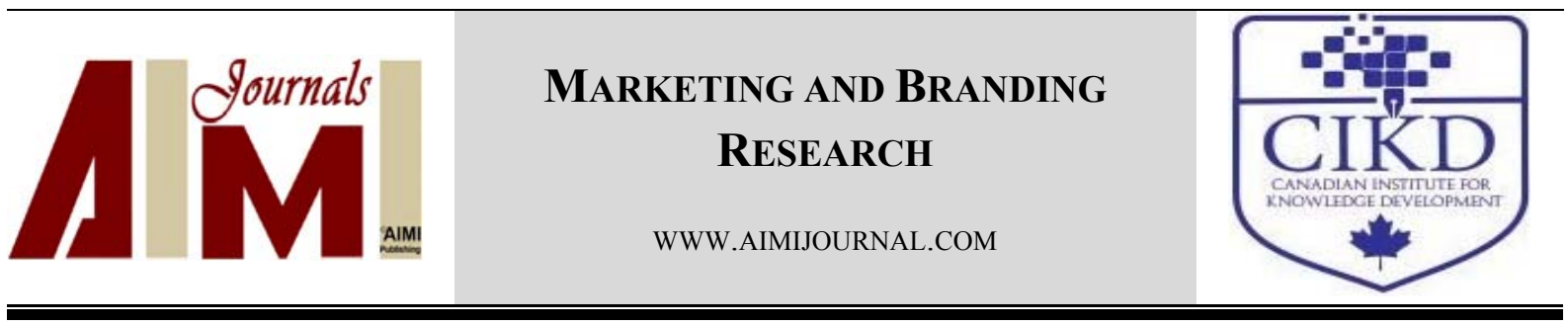

\title{
Use of Viral Marketing by Universities
}

\author{
Adriana Grenčíková ${ }^{1}$, Karol Krajčo ${ }^{{ }^{*}}$, Jakub Sokol ${ }^{1}$ \\ ${ }^{1}$ Alexander Dubček University of Trenčín, Slovak Republic
}

\begin{tabular}{|c|c|}
\hline & Abstract \\
\hline $\begin{array}{l}\text { Keywords: } \\
\text { Viral Marketing; Social } \\
\text { Networks; Education }\end{array}$ & $\begin{array}{l}\text { This study is an attempt to use a viral marketing at universities in Slovak and Czech } \\
\text { Republics. Social networks have become an everyday part of life. Permanent } \\
\text { communication takes place on social networks and it can be used by private companies } \\
\text { as well as other organizations. The social network can serve any organization to provide }\end{array}$ \\
\hline $\begin{array}{l}\text { Received } \\
27 \text { January } 2018\end{array}$ & $\begin{array}{l}\text { up-to-date information, respond to customer inquiries, and get quick feedback from } \\
\text { them, which is a huge asset. Social networks are becoming a means for companies to }\end{array}$ \\
\hline $\begin{array}{l}\text { Received in revised form } \\
\text { 10 June } 2018\end{array}$ & $\begin{array}{l}\text { find their customers' opinions about products. This helps to improve products and adapt } \\
\text { to current market needs. The aim of this study was to compare the use of social networks }\end{array}$ \\
\hline $\begin{array}{l}\text { Accepted } \\
17 \text { June } 2018\end{array}$ & $\begin{array}{l}\text { by universities as a modern marketing communications tool and to identify the success of } \\
\text { social networking. The basic methods were analysis, comparison and evaluation with the }\end{array}$ \\
\hline $\begin{array}{l}\text { Correspondence: } \\
\text { karol.krajco@tnuni.sk }\end{array}$ & $\begin{array}{l}\text { Social Scorecard. The final findings suggested the use of viral marketing by universities } \\
\text { and the improvement of viral marketing in the area of education. A marketing strategy } \\
\text { that is appropriately chosen and implemented on social networks can be much more } \\
\text { successful and more effective than the use of traditional marketing communication tools. }\end{array}$ \\
\hline
\end{tabular}

(CAIMI Journals

One of the possibilities of using ICT and Internet for marketing purposes is viral marketing. It is a technique that seeks to influence internet users to disseminate information about products, services and brands among themselves. This is a fairly cheap and very effective promotion in an ideal case (Blažková, 2005). This promotion, in the face of the growing use of social networks, is becoming more and more effective. Viral marketing can also be defined as a communication and distribution concept that relies on disseminating information between consumers within their social area through social networks and other electronic 
media (Helm, 2000). Viral marketing can be divided into two basic forms. The passive form is based on favorable consumer responses and does not seek to influence their behavior. The main goal of the passive form is to create favorable customer feedback by offering good quality goods and services. The essence of the active form of viral marketing is the effort to influence the consumer and thus to increase the sales of products and services, or to spread and consolidate brand awareness. As viral advertising can mark the message that attracts customers to the idea so much, it will begin to arbitrarily expand further (Madleňák, 2007).

Viral marketing is referred to as virus that spreads among humans as an infection. It moves, grows and can infect the environment (Godin, 2000). The bearer of this virus in this case is the product. Viral marketing benefits in particular from the existence of social networks. Advertisements spread among consumers are better than advertisements that are distributed directly by companies. Not every viral ad must always be successful, but if the intention is done as planned, it is a very effective and financially low-cost positive advertisement. The effectiveness of viral marketing lies in the fact that it conveys an implied endorsement from social ties (Mochalova \& Nanopoulos, 2014). The role played by viral marketing has received considerable academic and digital media attention recently. Key issues in viral marketing have been examined through the lens of the mode of marketing message transmission, including self-replicating on the basis of quality difference, individuals' emotional needs, as well as how users are connected across various social networks (Tsang \& Ren, 2015).

Social networks have become a phenomenon of the 21 st century. We meet the concept of the social network on a daily basis used by many people. Among young people, there is probably no one in a civilized world who would not come into contact with social networks. Social networks bring together billions of people around the world and connect them through their activities or interests. There is a huge scope for using these media for marketing purposes. We can define them as places where people meet to create a circle of their friends or join a community with common interests. Social networking is also called social networks, or simply just community. There are different types of networks. Most of them are the expanded personal social networks, of which Facebook is the most important (Janouch, 2010). For the social network, we also consider an internet service that gives its users the ability to create a personal profile and a list of people to create and display relationships (Boyd, Ellison, \& Nicole, 2007). The main goal of social networks is not to get acquainted with new people, but to interact and communicate with real-life friends.

The growth of technological progress and also constantly increasing computer literacy of the population causes an increase in the number of social networks and their use. Convenient and simple control is the key to the success of social networks. Social networks are becoming a common part of life, especially for young people, by developing mobile technologies and mobile applications. The growth of social networking can be dated to the period of qualitative Internet transition from Web 1.0 to Web 2.0, what we can call the transition to a new generation web (Velšic, 2012). Web 2.0 has brought a better design that promotes user creativity, helps to better share information, and enables collaboration between users. 
Advanced technologies have so greatly helped to develop the second generation of web communities to enable services such as social networks, file sharing systems, and blogs. Social networks are gradually becoming a daily part of people's lives. Marketing must also take account of this phenomenon. There is a constant communication on social networks, which can be used not only by private companies but also by other organizations. Social networks can serve to provide up-to-date information, respond to customer inquiries, and get quick feedback to any organization, which is a huge asset. Social networking has become a means for companies to ascertain the views of customers on products, it helps to product improvement and adaptation of current market needs (Janouch, 2010). The number of social networks is constantly growing and their primary focus is different. We recognize the various professional social networks, free-time social networks, as well as networks that help in education.

\section{Method}

The aim of this study was to compare the use of social networks by universities as a modern marketing communications tool and to identify the success of social networking. The comparison was performed using the Social Scorecard form developed by LiveWorld, based in California. The following faculties with economic focus were included in the evaluation: Faculty of Socio-Economic Relations of A. Dubcek University of Trenčín; Faculty of Economics of the Technical University in Košice; Faculty of Economics, University of Economics, Bratislava; Faculty of Economics and Administration, Masaryk University in Brno; Faculty of Management and Economics of Tomas Bata University in Zlín.

We submitted the assessment of faculty sites on Facebook and took place in three basic categories. These were categories of engagement, culture, and degree of interconnection with other communication channels. Each faculty could receive a maximum of 50 points. For the category, the exposure was maximum 25 points, in the culture category 16 points and 9 points in the category of interconnection with the other communication channels. On the basis of the points obtained, we have included the faculty in four basic categories, the beginner, advanced beginner, and the advanced and the expert.

\section{Results of the Survey}

Analyzed the Facebook page are equally focused, yet are different. Each was founded at another time, each faculty has a different number of students and the number of fans is different. The site of the Faculty of social and economic relations of A. Dubček University of Trenčín was established in September 2015 and is the second youngest. On the contrary, the second oldest is the site of the Faculty of Economics at the Mendel University in Brno, which was established in December 2011. The Facebook page of the Faculty of Economics of the Technical University in Košice started its activity in December 2013. At the latest, the website of the Faculty of Economics of the University of Economics in Bratislava was created in January 2016. The Faculty of Management and Economics of Tomas Bata University in Zlín has the oldest page that joined in June 2010. Based on the above information, it is clear that the foundation date affects the number of fans. That's exactly why we've recalculated the number of fans per day for a site's performance, which is a more 
relevant success rate indicator. Table 1 shows the average daily increment of fans since the start of the faculty page.

Table 1

Average Daily Increment on Facebook Pages

\begin{tabular}{lll}
\hline Faculty & Total fans & Average daily increment of fans \\
\hline FSEV TNUNI & 1420 & 2.7 \\
EkF TUKE & 1588 & 1.37 \\
NHF EUBA & 718 & 1.8 \\
FME UTB & 3040 & 1.25 \\
PEF MENDELU & 4716 & 2.38 \\
\hline
\end{tabular}

Source: own research

According to the survey in Table 1, the Faculty of Management and Economics of Tomas Bata University in Zlín has the lowest average increment. The website of the Faculty of Social and Economic Relations of the A. Dubcek University of Trenčín grows fastest. Figure 1 confirms this fact, which shows the number of fans of all facebook pages growing within the monitored period in January 16, 2017 - February 15, 2017.

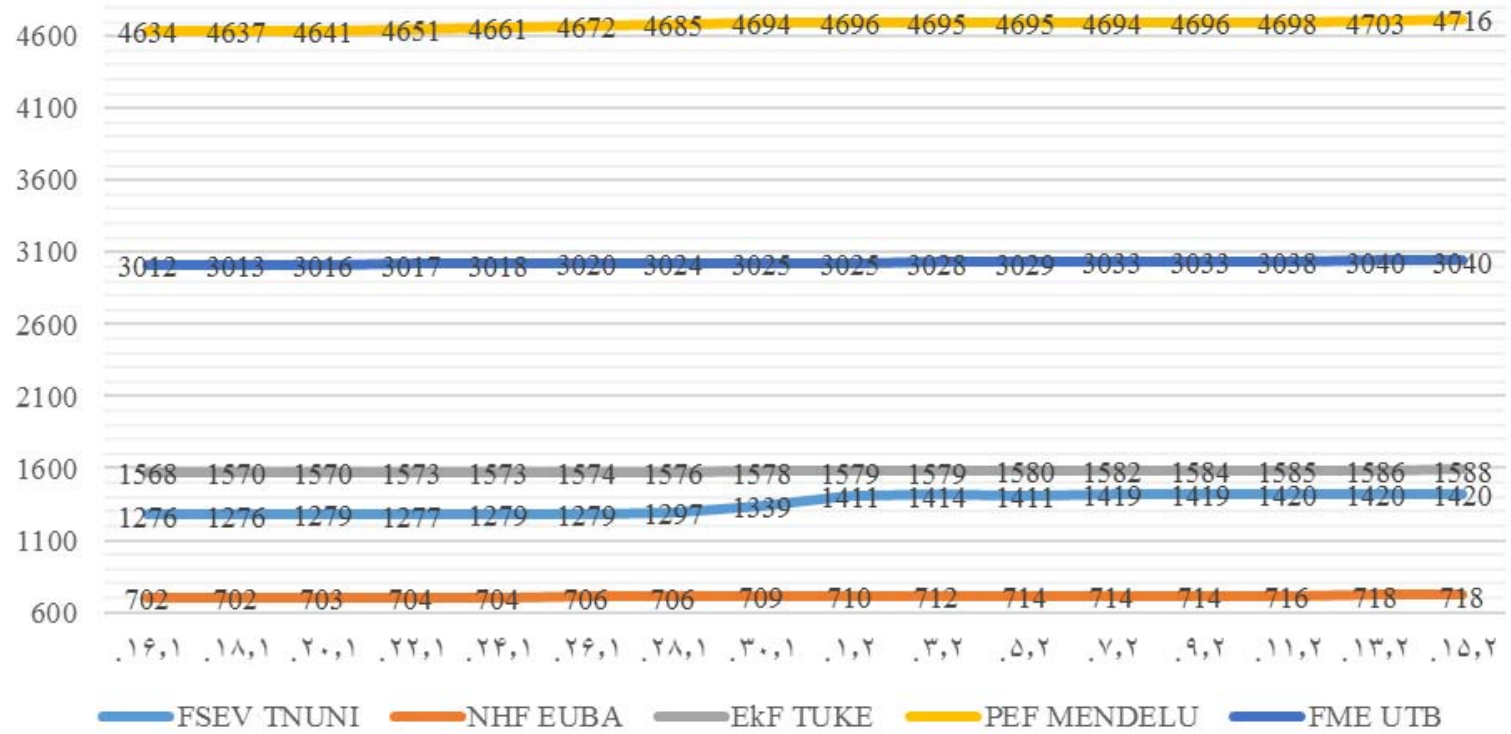

Figure 1. Development of the number of fans faculty pages in the period (16/1- 15/2/2017) Source: own research

As presented in Figure 1, we can see the gradual increase in the number of fans at the four faculties. The exception is the site of the Faculty of Social and Economic Relations, which is growing rapidly not only in the long term but we found significant increase in monitored period. The slowest growth within the monitored period was found at the Faculty of Economics of the University of Economics in Bratislava and at the Faculty of Economics of the Technical University in Košice. Another very interesting comparison is the share of domestic and foreign fans of faculty sites. Based on this share, we can deduce the 
attractiveness of faculties for foreign fans and students alike. The share of domestic and foreign fans is shown in Figure 2.

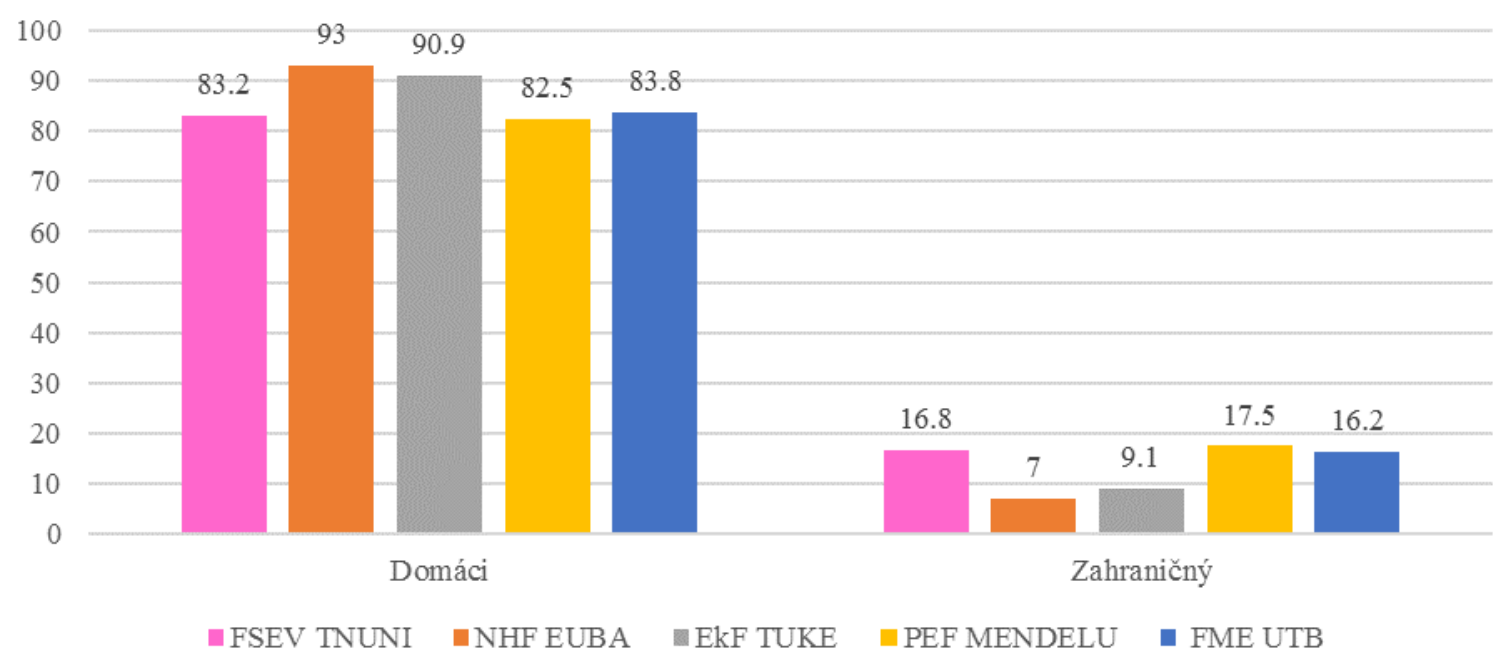

Figure 2. The share of domestic and foreign fans of sites (\%) Source: own research

We found strong domination of home fans for each school. We see more significant shares of foreign fans at both faculties from Czech Republic. Very interesting is the relatively high proportion of foreign fans at the Faculty of Social and Economic Relations. This share is worth $16.8 \%$, which is significantly higher than at the Faculty of Economics of the Technical University in Košice and the Faculty of Economics of the University of Economics in Bratislava. This share is even higher than at Tomas Bata University in Zlín, Faculty of Management and Economics.

The variety of shared content is another important comparison. The attractiveness of facebook sites is directly dependent on the attractiveness of the published content. Site administrator is responsible for adding content and should observe a certain balance between the types of posts. Excessive dominance of one type of contribution leads to monotony, which can be one of the reasons for failure. The share of photos, videos, shared links, and statuses should be approximately the same. Exceptions are photos that show a high share of popularity on facebook fans. Photographs are welcomed by their slight dominance. The faculty's pages show greater success of the photos with students. Figure 3 compares the typological composition of the posts that are on faculties facebook pages. 


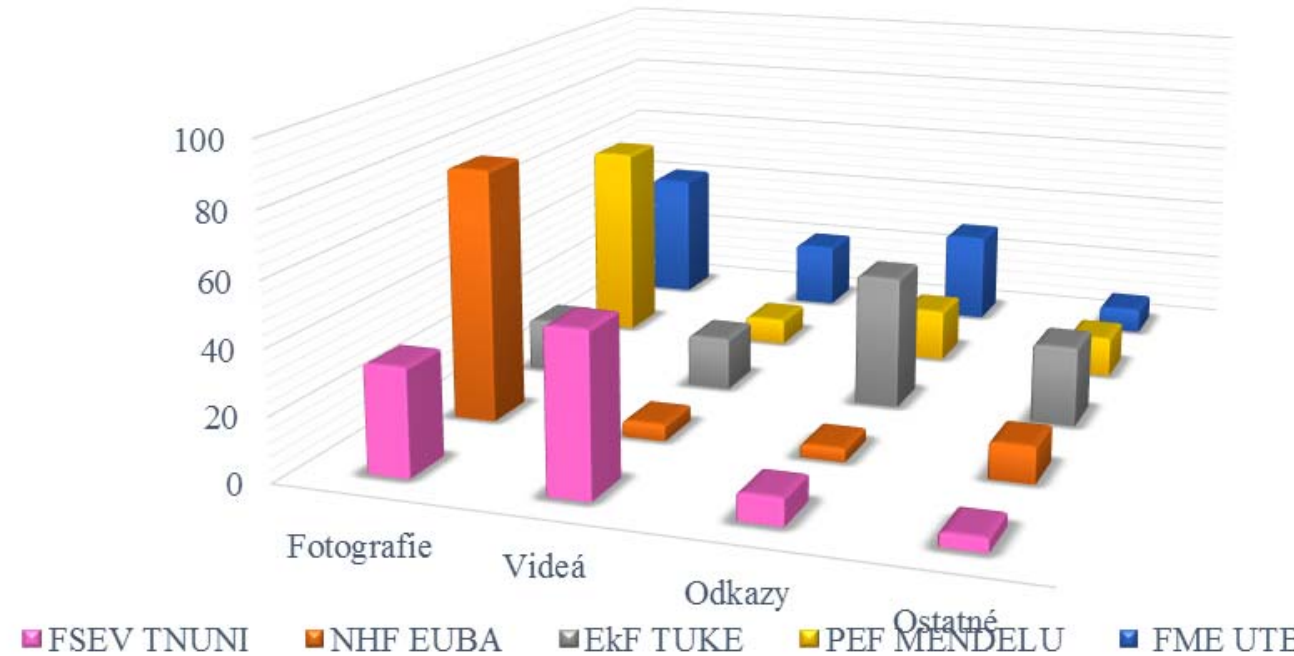

Figure 3. Variety of type of posts Source: own research

We can notice the frequent dominance of the same kind of contributions in Figure 2. The best balance of contributions can be seen at the Faculty of Management and Economics of Tomas Bata University in Zlín. On the other hand, the Faculty of Economics of the University of Economics in Bratislava has the worst balance. Although it is the dominance of photos, but in vast disproportion to other contributions. We notice a slight imbalance in shared contributions in the case of the site of the Faculty of Social and Economic Relations. This imbalance was caused by a competition that consisted of uploading a promotional video for the faculty. The videos were filmed by faculty students and all were published on the facebook page. This competition resulted in increased domination videos, which compensates for the gradual addition of other types of contributions.

Comparison of all the analyzed schools within the Social Scorecard evaluation form is another comparison in the evaluation of the results. The first category was the category of “involvement.

Table 2

Comparison in Involment Category

\begin{tabular}{|c|c|c|c|c|c|}
\hline Involvement & 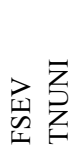 & 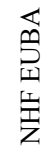 & 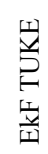 & 至 & 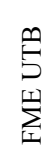 \\
\hline Regularity of adding content by admin & 2 & 3 & 1 & 4 & 4 \\
\hline Thematic suitability of published posts & 5 & 5 & 5 & 5 & 5 \\
\hline Involvement rate & 2 & 2 & 2 & 5 & 1 \\
\hline Rate of variety of shared content & 3 & 2 & 2 & 4 & 5 \\
\hline The quality of the involvement of fans & 3 & 2 & 2 & 4 & 2 \\
\hline Total & 15 & 14 & 12 & 22 & 17 \\
\hline
\end{tabular}

In the area of regularity of adding content by admin, various points were awarded. The best rating was given to faculties from the Czech Republic. On both pages, the content grows 
regularly and quite often. Worst rating page was for Economics Faculty of the Technical University in Košice. Posts were not frequent and on a regular basis. It can be attributed to the malfunction of the site, as there was a more frequent contribution in the past, and the site had the proper attention of the administrators. Each of the faculties evaluated has room for improvement.

As part of the thematic suitability of published contributions, we decided to give all faculties a full score. We did not find inappropriate content and content that was significantly disturbing on any page. Each page holds a college theme, shares photos from school events, articles about faculty achievements, students, and educators. Within this area, we had no major reservations for analyzed faculties.

Involvement rate is one of the most significant short-term indicators of the attractiveness of facebook sites. Several methods are used to calculate it. In our case, we used the method in which we calculate the proportion of "people who talk about it," and the total number of likes, shares, and comments for the past week. In this case, the positive threshold was $7 \%$. Over the border was only the facebook page of the Faculty of Economics at Mendel University in Brno, for which we gave it 5 points. Involment rate is a short-term indicator, but it is more important. Successful sites tend to hold positive values and level of involment in the long term.

In the category of variety of shared content, we awarded the full number of points only to the Faculty of Management and Economics of Tomas Bata University in Zlín. On the page we found the most balanced ratio of different types of posts. The second highest number of points was awarded to the Faculty of Business and Economics of Mendel University in Brno. The share of photos was higher. We found a lot of student photos that were very popular with fan site. In all analyzed faculties in Slovakia, we can find a lower level of content variability. The lowest level of engagement was recorded at the Faculty of Economics of the Technical University in Košice.

In the category of fan participation, the rate was assessed by the presence of the content to which it was easy to react. The Faculty of Business Economics at Mendel University in Brno was the best in this category. We found competitions and status queries. Only this faculty used funny pictures about students life. All these posts were successful with the fans and encouraged their activity. For Slovak faculties, this type of content was not very common. The exception was the site of the Faculty of Social and Economic Relations of Alexander Dubcek University of Trenčín. On the site, we found a competition for the best promotional video, which aroused quite a lot of interest. The competition consisted of making videos and likes collecting. The winning video had 1,321 likes, that shows a high activity of fans pages and their involvement in the operation of site.

The highest number of points in the category of engagement was acquired by facebook of the Faculty of Business and Economics of Mendel University in Brno. The second best site was the Faculty of Management and Economics of Tomas Bata University in Zlín. On third place was Faculty of Social and Economic Relations of Alexander Dubcek University of Trencin. Faculty of Economics of the University of Economics in Bratislava was on the fourth place. The last place was for Faculty of Economics of the Technical University in Košice. 
Table 3

Comparison in the Category of Culture

\begin{tabular}{|c|c|c|c|c|c|}
\hline Culture & 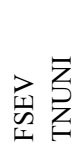 & 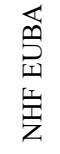 & 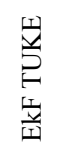 & 空 & 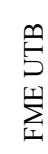 \\
\hline The presence of communication rules and their quality & 2 & 3 & 3 & 4 & 3 \\
\hline Troubleshooting and Conflict Resolution & 2 & 3 & 2 & 4 & 2 \\
\hline The impact of the site on building a name & 3 & 3 & 3 & 3 & 3 \\
\hline The ability of the site to be in fan awareness & 3 & 2 & 2 & 3 & 3 \\
\hline Total & 10 & 11 & 10 & 14 & 11 \\
\hline
\end{tabular}

The elaboration and publication of communication rules was evaluated within the category of the presence of communication rules and the quality of communication; we focused mainly on the quality of communication. In previous sections, we noticed a lower need for communication rules on this type of site. It's a non-commercial site, and none of the sites has a huge number of fans. For these reasons, we focused primarily on the quality of communication. The full number of points was awarded only to the facebook page of the Faculty of Business and Economics at Mendel University in Brno. Admins answered all fan queries very quickly and well. The communication was at an excellent level and often with a certain amount of humor. Private messages were answered in a few hours, and we were also persuaded to obtain some information. Higher number of points were awarded to the Faculty of Economics of the Technical University in Košice. The answer to private messages was also quick and we also appreciated the section on the facebook page, which was called "students ask". Queries that were posted on the site were answered. The promptness of responses to private messages and the response to fan questions on wallpapers were also appreciated by the pages of the Faculty of Economics of the University of Economics in Bratislava and the Faculty of Management and Economics of Tomas Bata University in Zlín. The site of the Faculty of Social and Economic Relations received the lowest score in this category. The response to private messages was satisfactory, but there were unanswered questions from fans on the wall. In this area, we identified the possibility for improvement.

In the problem and conflict resolution category, we evaluated how administrators could deal with problematic and conflicting situations. Within this category, only the site of Economics Faculty of Mendel University gained full points. As such situations arose, administrators responded, tried to solve them and propose solutions. Even on the basis of this situation, regular page care, fast responses to reports, we anticipated a quick fix of the issues and we gave highest number of points. Also, one situation arose on the site of the Faculty of Economics of the University of Economics in Bratislava and also came to a reaction, though not as prompt as the previous page. On other Facebook sites, conflicts did not occur, we did not expect to neglect and escalate any conflicts that may arise. This is based on quick responses to reports and less or more regular site care.

In the category of impact on building a name, we gave 3 points to all pages. Each analyzed page has an impact on building a name, as it published relevant information about faculties, 
highlighted the successes of faculties, students and educators. Sites provided information to their fans, information that might be left unnoticed. Every page attempted to highlight the positive aspects of the faculty. Therefore, they had a share in building a good name for their fans.

Pages from the Czech Republic were better in the category of ability to be in fan awareness. The Facebook pages of the Faculty of Economics at Mendel University in Brno and the Faculty of Management and Economics of Tomas Bata University in Zlín received 3 points. Contributing was fairly common and content relevant. The information contributed to their fans' awareness. In the case of the Faculty of Social and Economic Relations, we also awarded 3 points in the presence of content that could be easily answered. For the other faculties, we gave a lower score due to a lower frequency of contribution and a lack of social content.

The last part of the Social Scorecard evaluation form was the category of linking with other communication channels. Connecting social networks with other communication channels is immensely important. It makes it easier for users to acquire complex information by linking to other social networks as well as by linking with faculty and university sites.

Table 4

Comparison in the Category of Interconnection with Other Communication Channels

\begin{tabular}{|c|c|c|c|c|c|}
\hline Linking with other communication channels & 焉笲 & 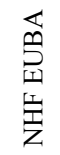 & 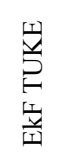 & 至空 & 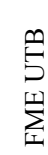 \\
\hline Existence of motivating content to share & 3 & 1 & 1 & 3 & 1 \\
\hline The existence of interconnection elements to the school website & 2 & 2 & 2 & 2 & 2 \\
\hline The presence of social plugins on the page & 1 & 2 & 1 & 1 & 1 \\
\hline Total & 6 & 5 & 4 & 6 & 4 \\
\hline
\end{tabular}

The existence of motivating content to share is one of the key features of a successful facebook page that is used for marketing purposes. The full number of points was awarded to the Faculty of Socio-Economic Relations and the Faculty of Business and Economics of Mendel University in Brno. We found competitions (ball tickets, best video) for that stimulate activity at the page of FSER. The Faculty of Business Economics also gained full points. There was no competition on the wall, but there were question statuses, funny pictures, and student photos that support sharing. For the rest of the sites, we decided to award only one point because we did not find this type of content on the site or only in the minimum amount.

Within the category of existence of interconnection elements to the school website, we awarded 2 points to all the analyzed pages. On all facebook sites, we found a direct link to the faculty page via a hyperlink in the "home" section and in the "information" section. We did not give full score, because we did not find a direct link to the university website.

In the category of social plugins, we identified greater deficiencies in almost all of the pages analyzed. Two points were awarded only by the Faculty of Economics of the 
University of Economics in Bratislava. Below each article, we found buttons that made it easy to share and link to social networks such as Twitter, Google+, LinkedIn, Pinterest, and other social networks. Negative is the impossibility of commenting and discussion on the site. We did not find social plugins on other sites and an option to comment on the articles. The link to the facebook page was often placed inappropriatly which made it impossible find it intuitively.

Table 5

Comparison of Social Scorecard Evaluation

\begin{tabular}{|c|c|c|c|c|c|}
\hline Comparison of Social Scorecard evaluation & 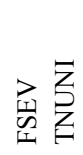 & $\begin{array}{l}\overleftrightarrow{m} \\
\text { 号 } \\
\text { 声 } \\
\text { 艺 }\end{array}$ & 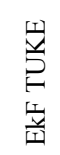 & 乩空 & 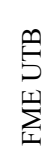 \\
\hline Involment & 15 & 14 & 12 & 22 & 17 \\
\hline Culture & 10 & 11 & 10 & 14 & 11 \\
\hline Linking with other communication channels & 6 & 5 & 4 & 6 & 4 \\
\hline Total & 31 & 30 & 26 & 42 & 32 \\
\hline
\end{tabular}

We evaluated facebook pages of selected faculties of economics using the Social Scorecard. The facebook page of the Faculty of Business and Economics of the Mendel University in Brno was placed first. From 42 points, we could include it in the "expert" group. The Faculty of Management and Economics of Tomas Bata University in Zlín was second placed. The faculty obtained 32 points and placed in the "advanced" group. The best Slovak analyzed page was the site of the Faculty of Social and Economic Relations. It gained 31 points and placed in the "advanced" group. Faculty of Economics of the Economic University in Bratislava gained 30 points, which included the faculty in the "advanced beginner" group. The Facebook page of the Faculty of Economics of the Technical University in Košice finished last and with 26 points placed in the "advanced beginner" category. We identified the positive and negative of facebook pages of selected faculties of universities by evaluating the Social Scorecard. Based on the analysis, we concluded that each site had the potential to improve and thus maximize their marketing potential.

\section{Conclusion}

Social networks have become a phenomenon of the 21 st century. We are coming into contact with social networks more and more often which penetrate into the everyday life of a large number of people. This has both positive and negative aspects. The positive aspects are related to the fast and efficient communication, or fast linking of interesting contacts. One of the negative aspects of using social networks is their overuse, which poses a threat to the social isolation of users in the real world. In general, we can claim that the positive aspects outweigh the negatives ones. One of the biggest benefits is the worldwide use of social networks, which has a huge potential in their effective use in marketing communications. Properly chosen marketing strategy implemented on social networks can be much more successful and more effective than using traditional marketing communication tools. Social 
networks bring together billions of potential customers, have global reach, allow accurate targeting of the target audience, and are a relatively low cost.

The use of social networks is not only a domain of individuals but also of companies. If a company wants to be successful, it must adapt to current trends and develop activity on the most widespread social networks. Properly set up and managed page becomes as a major competitive advantage and a tool for acquiring customers, creating a good name and building awareness about the company. A site on the social network can be compared with a shop window showcase. A lot of customers decide to enter the shop (if they see something interesting in the window showcase or if they have good feelings).

The development of marketing activities on social networks does not only concern with companies but also universities and their faculties. Young people are grouped on a large scale on social networks which represent the main target group for university faculties. Most universities are aware of this fact and develop social networking activities, especially on the Facebook social network. Even in this case, if severals do the same, the results may not be exactly the same. Creating an account is not the end but it all starts. Extremely important role is a regular care, regular activity, and an attractive content on the site.

\section{References}

Blažková, M. (2005). Jak využit internet v marketingu. Praha: Grada Publishing.

Boyd, D., Ellison M., \& Nicole M. (2007). Social network sites: Definition, history, and scholarship. The Journal of

Computer-Mediated Communication, 13(1), 210-230.

Digizen (2013). Young people and social networking services. Dostupné na. Retreived from http://digizen.org/socialnetworking/sn.aspx >

Godin, S. (2000). Unleashing the ideavirus. Chicago: Dearborn Trade Publishing.

Helm, S. (2000). Viral marketing-establishing customer relationships by'word-of-mouse'. Electronic Markets, 10(3), 158161.

Janouch, V. (2010). Internetový marketing (Internet Marketing). Praha: Computer Press.

Madleňák, R. (2007). Internetový virálny marketing: Moderná metóda získavania zákazníkov. Pošta: Telekomunikácie a Elektronický obchod.

Mochalova, A., \& Nanopoulos, A. (2014). A targeted approach to viral marketing. Electronic Commerce Research and Applications, 13(4), 283-294.

Tsang, D., \& Ren, Q. (2015). Viral marketing and the new competitive advantage. Journal of Organisational Studies and Innovation, 41-54.

Velšic, M. (2012). Sociálne siete na Slovensku. Bratislava: Inštitút Pre Verejné Otázky. 